\title{
Analysis of Taxation of Property in Bosnia and Herzegovina
}

\author{
Lejla Lazović-Pita \\ University of Sarajevo, Bosnia and Herzegovina \\ lejla.lazovic@efsa.unsa.ba \\ Amina Močević \\ Sarajevo Canton, Ministry of Finance, Bosnia and Herzegovina \\ amina.mocevic@mf.ks.gov.ba
}

\section{ABSTRACT}

The purpose of this paper is fill in the literature gap and to analyse taxation of property in Bosnia and Herzegovina (BIH). By using IMF and OECD methodology defined under taxes on property, our research tries to compare taxes on property in two BIH entities to the international practice. The results are twofold: firstly, inconsistencies to international classification of taxes on property in BIH are identified and secondly, the taxation of property differs in two BIH entities (RS and FBIH). We find that three different types of property taxes are applied -tax on immovable property in RS and real estate transfer tax and so called tax on property in FBIH. We also find that identified differences have an effect on the size and share of revenues from property taxes in both entities which affect local communities and their revenues. Hence, we focus on property taxes in FBIH since they are under cantonal jurisdiction. The research shows that most revenues from property taxes in FBIH are collected in Sarajevo Canton. In fact, most property tax revenues in Sarajevo Canton come from real estate transfer tax revenues and are collected in four municipalities forming the City of Sarajevo. Bearing in mind lack of reliable long term data in both BIH entities related to taxation of property, we conclude with a few policy recommendations and suggestions for future FBIH property related reforms which should in turn simplify the process of property taxation in FBIH and improve the position of local communities in $\mathrm{FBIH}$.

Keywords: Bosnia and Herzegovina, local government units, property taxes, real estate transfer tax

\section{Introduction}

Even though issues related to taxation of property are gaining prominence in the European Union (EU) member states in the last few years (Garnier et al., 2014; the European Commission, 2015), different types of taxation of prop- 
erty are still an unexplored area of taxation in BIH. Since revenues from property taxes usually belong to local government units (LGUs) - municipalities and cities, property taxes are usually evaluated through their significance to local revenues. The position of LGUs and the importance of property taxes is mostly used in the analysis of the level of fiscal decentralisation in a country. Early papers related to property taxes in BIH are scarce except from a few ones such as Fox and Wallich (1997), Zorn et al. (2000), Jokay (2001) or Werner et al. (2006). Most papers do not focus solely on property taxes in BIH but relate to overall tax system in $\mathrm{BIH}$, the position of LGUs or concepts of fiscal federalism in BIH (for example, Davey, 2011; Antić, 2013).

Unlike BIH case, the research dealing with taxation of property is relatively comprehensive for other transition countries especially in cross-country comparisons. Most papers deal with definition, status and undertaken property tax reforms in transition countries especially Central and Eastern European countries (for example, The World Bank, 1999; Almy, 2001; Malme \& Youngman, 2001; McCluskey and Plimmer, 2007; 2011 or Bahl, 2009; 2013; Puleri \& Kripa, 2016; Grdinić et al., 2017; Grover et al, 2017). The results of such research usually focus on identifying major obstacles, common for all Central and Eastern European countries, which evolve around underdeveloped property markets, aspects of decentralisation and privatisation processes in these countries. BIH is mostly excluded from any these analyses as well as other Western Balkan countries.

The aim of this paper is to provide legal and fiscal analysis of taxation of property in $\mathrm{BIH}^{1}$. Due to complex constitutional organisation of $\mathrm{BIH}$, the taxation of property differs in two BIH entities which in turn puts LGUs in two entities into unequal position in terms of the size of revenues from property taxes. Different constitutional organisation of Federation of Bosnia and Herzegovina (FBIH) and Republika Srpska (RS) might give some explanation to the existing interentity difference but other reasons also exist - such as different approaches to taxing property so intra-entity differences also exist especially in $\mathrm{FBIH}$.

We begin our analysis with the definition of taxes on property as defined by international financial institutions such as OECD (2017) and IMF (under GFS², 2014). Taxes on property are "taxes payable on the use, ownership or transfer of wealth" which are levied regularly (usually annually) or irregularly (IMF, 2014, p. 93). Hence, OECD and IMF together with EC similarly classify taxes on property as recurrent (and non-recurrent) taxes on immovable property or net wealth, taxes on the change of ownership of property through estate, inheritance or gift and taxes on financial and capital transactions (OECD, 2017). Hence, we start our analysis with the definition of taxes on property in $\mathrm{BIH}$ in comparison to aforementioned international classifications. By identifying the differences in BIH classification to the international classification, our aim was to contribute towards improvements in the definition, comprehensive-

1 Brčko district will not be analysed due to the scope of the paper.

2 Similar classification can also be found in European Commission (EC) related documents. 
ness and classification of taxes on property in BIH and related property taxes statistics in $\mathrm{BIH}$. So, the research will be divided into four main parts: the first part will give a brief relevant literature review of property taxation in two $\mathrm{BIH}$ entities. The second part focuses on methodology and legal framework of taxing property in $\mathrm{BIH}$ and provides an analysis of taxes on property in $\mathrm{BIH}$ under IMF and OECD methodology. Hence, the third part provides a comparative analysis of taxation of property in two BIH entities with a special focus on complex FBIH case. Since property taxes are under cantonal jurisdiction in $\mathrm{FBIH}$, we will analyse the share of property tax revenues to total revenues in each Canton. We then focus on the case of Sarajevo Canton since it collects most revenues from property taxes in $\mathrm{FBIH}$ (in both absolute and relative terms). We also evaluate the position of inner and outer city municipalities in this canton. Under definition and methodology provided in McCluskey and Plimmer (2011), Central and Eastern European countries and hence BIH could have an option of taking advantage of greater fiscal space created under taxes on property which could bring several benefits to entire tax system and especially for LGUs revenues. Bearing in mind lack of reliable long term data in both BIH entities related to taxation of property and based upon our analysis, in the final part, we propose a set of policy suggestions and recommendations for future successful property tax reform in (F)BIH. Also, in the discussion, we provide research limitations and future empirical research in property taxation in $\mathrm{BIH}$ which should enhance the system of taxation of property in $\mathrm{FBIH}$ and $\mathrm{BIH}$. We conclude that in FBIH future property tax reforms should aim at simplifying taxation of property by replacing the existing models of property taxation with recurrent taxes on immovable property.

\section{Literature Review of Taxation of Property}

After the outbreak of global financial crisis (GFC) in 2008, the interest and significance of taxation of property increased in the EU member states. In the Annual Growth Survey (2013), the European Commission (EC) recommended to its member states to undertake tax reforms and to shift away from taxation of labour to taxation of, inter alia, property taxes (Garnier et al., 2014). A shift towards a less distortive and a broader-tax-base taxes such as property taxes is significant and in the EU, most member states have undertaken property tax reforms or have been fine-tuning existing taxation of property in accordance with the EU suggestions and recommendations (Gayer and Mourre, 2012; Slack and Bird, 2014; the EC, 2015). These reforms are being monitored by the EC and published in most recent publications related to tax reforms (for example, The EC, 2015; The EC, 2017). In the OECD member states, there is traditionally long-term evaluation of the size of property taxes and their importance to LGUs. Recent OECD publications have dealt with good practices and solutions regarding different aspects of property taxes, such as valuation and assessment of immovable property in OECD countries and its partner countries (Almy, 2014), the impact of property and land taxes on 
environment (Brandt, 2014) or the political economy of property tax reforms (Bird and Slack, 2014). Countries such as United Kingdom, Ireland, Italy and Greece have most recently undertaken property tax reforms (Slack and Bird, 2014). Status and progress in the property tax reforms as a part of overall tax reforms are available annually in the EU publications (the EC, 2017). Similar to developed EU member states, transition countries that are EU members have mostly undergone property tax reforms even though they come last in the tax reform process. Significance of property tax reforms can be seen in recent research which indicates that property taxes are the least detrimental to GDP growth (Arnold, 2008., Arnold et al., 2011., Johansson et al., 2008 according to Rašić-Bakarić, 2014 and Grdinić et al., 2017) since they are implemented mostly through taxation of immovable property with broad tax base and traditionally low rates (Blöchlinger, 2015).

Analysis of different aspects of property tax reforms mostly include EU member states and new EU members from Central and Eastern Europe (CEE). By using a method of comparative analysis, authors such as Blažić and Grdinić (2012), Norregaard (2013), Rašić-Bakarić (2014) or Blažić et al. (2016) have summarised the status of property tax reforms in the EU member states and highlighted the differences in the taxation of property in EU member states with a special focus on CEE countries. Under works of these and other authors (for example, Bird \& Slack, 2002; Bahl \& Martinez-Vasquez, 2007; McCluskey and Plimmer, 2007; 2011; Norregaard, 2013; Ahmad et al., 2014; Blažić et al., 2016; Grover et al., 2017) a set of proposed suggestions and recommendations for successful property tax reforms is always provided and in this paper, we build on such experiences and try to adopt them to BIH case. Hence, most CEE countries have undergone property tax reforms and have implemented recurrent tax on immovable property. The differences that still exist between EU members relate to implementation of either area-based or value-based taxes on immovable property (real estate, Grover et al., 2017). EU 15 countries mostly apply "value-based taxes whereas new EU member countries apply area-based taxes" (Blažić et al., 2016, p.41). Unlike EU practice, research and evaluation of property taxes in Western Balkan countries and $\mathrm{BIH}$ is scarce. Individual country analyses of property taxation or planned property tax reforms in Central and Eastern European countries and Western Balkans were most recently re-initiated (for example the case of Croatia and prior Slovenian experiences in Kukić \& Švaljek, 2012; Blažić et al., 2016), but this is not the case of BIH. Research related to CEE countries and property tax reforms indexed in the Web of Science database (for period 1945-2018) cites some twenty papers out of which only seven are from the area of economics and only four directly relate to only property taxes and CEE countries already cited in this paper. However, none of these include any research related to property taxes in $\mathrm{BIH}$. Hence this paper analyses the status and property tax reforms undertaken in $\mathrm{BIH}$ in the past fifteen years. Papers from Fox and Wallich (1997), Zorn et al. (2000), Jokay (2001) or Werner et al. (2006) dealt with the status of property tax reforms in BIH in the late 1990s together with 
other fiscal or tax reforms. Most of the papers analysed property taxes in BIH together with other sources of revenues in the fiscal federalism model applied in BIH except Zorn et al. (2000) who elaborated why BIH should apply area-based property taxes. However, since 2000 , very little research has been done in the area of property taxes in BIH except a most recent research from Tadić (2016) who focuses on property tax reform conducted in RS entity and the economic effects of such reforms. So, we wish to fill in the literature gap and hence provide a brief legal and fiscal analysis of all property tax reforms in both BIH entities in the past fifteen years.

\section{Methods and Legal Framework of Taxing Property in BIH}

Theory (Jelčić \& Jelčić, 1998) and practice (ESA, 2010; IMF-GFS, 2014) identifies several types of property taxes. They are usually classified in accordance to OECD, EC or IMF classification (OECD, 2017; ESA, 2010; IMF-GFS, 2014) so taxation of property in all classifications includes taxation of immovable property, taxation of net wealth, estate, inheritance and gifts taxes and, most recently, taxes on financial and capital transactions (Raičević, 2008).

The primary purpose of this paper is to fill in the literature gap related to taxation of property for BIH as a Western Balkan country. In that sense, three research questions will be asked:

1. What types of taxation of property are applied in $\mathrm{BIH}$ (both entities) and to what extent are they in line with classification of property taxation in international practice?

2. Is there a difference in types and means of taxation of property in two BIH entities? Is the possible difference reflected in the size of revenues from property taxes to total taxes in two BIH entities?

3. Are property taxes a significant source of revenues and especially for LGUs in FBIH? Do LGUs in FBIH have a potential of creating a greater fiscal space for property taxes?

In order to answer the three research questions, we have to define the scope of taxes on property under international methodology. The international financial institutions (IMF and the OECD) define taxes on property under methodological notes in their publications (IFM-GFS, 2014 and OECD Revenue statistics, 2017). All definitions have a few peculiarities in the comprehensiveness and definition of types of taxes on property. Hence, as an answer to the first research question, we will compare the classifications of types of property taxes under IMF-GFS definition and OECD to BIH practice in both entities. Such analysis has not been previously done for the case of BIH and has caused several practical inconsistencies which are still applied in the BIH legislation. As an answer to the second question, we will use IMF-GFS data for the last fifteen years in order to determine the significance and the size of property tax revenues to total revenues and LGUs total revenues in both BIH entities. In or- 
der to answer the third research question we will focus on FBIH entity where most revenues for property taxes are collected in BIH. By using definition of fiscal space and methodology provided in McCluskey and Plimmer (2011), we wish to evaluate the size of property taxes in LGUs in Sarajevo Canton which collect most revenues from property taxes in entire FBIH. In the case study of Sarajevo Canton, we want to examine the possibility for creating a greater fiscal space for property taxes especially in the outer-city municipalities in comparison to inner-city municipalities since this pattern could then serve as an example for the entire FBIH.

In terms of limitations of this paper and possible future research, in the discussions and recommendations section, we will briefly analyse current state of poor and unreliable long term statistics related to property taxation in (F)BIH. Furthermore, we will provide possible future research activities in the area of property taxation that have begun in 2018 in $\mathrm{FBIH}$, so first results comparable to international practice and research could be expected in the coming years. Hence, this paper is the first of such kind that provides comparable legal and theoretical analysis of the taxation of property in BIH since 2003 until today.

\subsection{International classifications of taxation of property and BIH case}

We have previously stated that international financial organisations such as the IMF or the OECD provide a clear classification of taxes on property under methodological notes in two documents: IMF-GFS manual which is used to collect comparable cross-country data on government finances, and the OECD Revenue statistics for the same purposes comparable for the OECD members ${ }^{3}$. In the IMF-GFS manual $(2014$, p. 93), taxes on property are defined under group 113 and divided into five categories: (i) recurrent taxes on immovable property; (ii) recurrent taxes on net wealth; (iii), estate, inheritance and gift taxes; (iv) capital levies and (v) other recurrent taxes on property. Each group is then defined, explained and placed into broader picture of SNA methodology. Similarly, the OECD (2017) provides a somewhat more detailed classification of taxes on property which are defined under group 4000, and arranged as recurrent and non-recurrent taxes on property and divided into six categories: (i) recurrent taxes on immovable property; (ii) recurrent taxes on net wealth; (iii) estate, inheritance and gift taxes; (iv) taxes on financial and capital transactions; (v) other non-recurrent taxes on property and (vi) other recurrent taxes on property. Again, each group is defined and explained. We will follow the two definitions and provide a comparison to BlH case (both entities).

In $\mathrm{BIH}$, due to its peculiar constitutional organisation, property taxes are under entity's jurisdiction -RS and FBIH. In RS, property taxes are regulated by law brought at the level of RS entity and revenues from property taxes usually belong to LGUs. Since 2003, there have been a few legal changes and amend-

3 Similar classification could also be found in the annual EC publication - Taxation trends in the EU. 
ments. From 2002 until legal changes in 2008, RS applied both area-based property tax depending on the type of immovable property and real estate transfer tax as a type of tax on capital transfers. Tax rate was determined per $\mathrm{m}^{2}$ depending on the type of immovable property whereas real estate transfer tax rate was set at 3 per cent. In 2008, RS brought a new law as a part of comprehensive property tax reform - tax on immovable property. According to Antić (2013), the comprehensive property tax reform in RS began in 2012 but some legal changes occurred in 2008 and were implemented in 2009 with the introduction of synthetic personal income tax. This especially relates to sources of income coming from property such as income from rent or property rights which are classified under comprehensive or broad definition of income according to Schanz-Haig- Simons (SHS) definition of income (Blažić, 2006; OECD, 2006). RS does not apply inheritance and gifts tax.

The application of the new tax on immovable property in RS was legally set to year of 2010, but it became operational in 2012 as set of other property related factors were established - such as fiscal register and mass valuation of immovable property. This law went through a few legal changes from 2012 until 2017. The tax rates were set from minimum 0.05 per cent up to 0.5 per cent of the estimated market value. Current rate of up to 0.2 per cent of the estimated market value was set in 2016 with the new law. Rate of up to 0.1 per cent can only be applied for the production facilities. Since all revenues from property taxes belong to municipalities and cities in RS, municipal assemblies are obliged to inform the tax administration of RS of the value of the real estate by zones within the municipality/city as well as the size of the tax rate not exceeding 0.2 per cent. There are more than 60 LGUs in RS, so tracking the methodology applied for determining the tax base and tax rates is a time consuming and relatively expensive process in RS Tax administration (Tadić, 2016).

Unlike RS, in FBIH, property taxes are not regulated at the level of FBIH, but rather at the intermediate sub national level of government- Cantons. In ten cantons of Federation there are twenty laws which regulate property taxes a law on taxes on property and real estate transfer tax in each of ten cantons. Taxation of inheritance and gifts is usually included in one of the two laws in each canton. Similar to the case of RS, in FBIH with the introduction of synthetic personal income tax in 2009, cantonal 'laws on taxes' had to be modified as some sources of property income, such as income from rent or property rights were included in the personal income tax base. Both legal changes and inclusion of specific sources of property income to personal income tax are in line with both IMF-GFS and OECD methodology classified under Taxes on payroll and workforce (OECD, 2017; IMF, 2014). In the period 2003-2017, a few legal changes and amendments occurred in ten FBIH cantons, but were generally insignificant modifications to a property taxation model established in late 1990s.

In terms of comparison of BIH legislation in two entities to international practice, table 1 provides a comparable summary. 
Table 1: Comparison between international classifications of taxes on property and BIH classification, 2018

\begin{tabular}{l|l|l|l|}
\hline \multicolumn{1}{|c|}{ Taxes on property } & RS & FBIH \\
\hline Recurrent taxes on immovable property (IMF+OECD) & + & - \\
\hline Recurrent taxes on net wealth (IMF+OECD) & - & - \\
\hline Estate, inheritance and gift taxes (IMF+OECD) & - & + (some cantons) \\
\hline Capital levies (IMF) & - & - \\
\hline Other recurrent taxes on property (IMF) & - & - \\
\hline Taxes on financial and capital transactions* (OECD) & - & + \\
\hline Other non-recurrent taxes on property (OECD) & - & - \\
\hline Other recurrent taxes on property (OECD) & - & - \\
\hline * IMF-GFS (2014) classifies these taxes under Taxes on goods and services, namely, under \\
sub-group of value-added taxes (11414) but the name of the category is the same in OECD \\
and IMF classification (Taxes on financial and capital transactions).
\end{tabular}

Source: IMF, 2014 \& OECD, 2017, own interpretation.

From table 1, we can determine that very few types of taxes on property classified under international classifications exist in BIH under BIH entity's classification of property taxes. However, when we try to interpret the information provided in table 1 and compare it to BIH case (both entities), we have to be very careful especially due to myriad of property related tax laws in BIH. For the RS case, most recent property tax reform and the introduction of taxes on immovable property in RS moved property taxation into right direction due to base broadening and very low property tax rates. RS abolished several types of property taxes (real estate transfer tax, inheritance and gift taxes). However, some types of property, such as movable property (for example motor vehicles) are not included in this classification of property taxes. In RS, motor vehicles are taxed by different law that regulates, inter alia, the use of motor vehicles and the tax is paid depending on the engine volume. Under such explanation, this type of tax would mostly suit IMF classification of 'motor vehicle taxes' classified under Taxes on Use of Goods and on Permission to Use Goods or Perform Activities (11451, or 5200 under OECD classification).

From table 1 we could determine that $\mathrm{FBIH}$ is lagging behind in the $\mathrm{BIH}$ property tax reforms as the situation in FBIH property taxes is very complex since it includes twenty cantonal laws with several types of property tax. As noted before, in FBIH since 2003, all cantons define two tax property related laws: tax on property including both movable and immovable property and real estate transfer tax which includes transfer of immovable property but in some cantons it also defines segments of inheritance and gift taxes. Tax on prop- 
erty includes both movable (for example cars) and immovable property (for example houses or flats for recreation) but excludes financial property. Since 2003 until 2017, very few legal changes occurred in this area. Table 2 tries to summarise the main inter-canton comparable categories of immovable and movable property defined under ten cantonal laws. The categories under both movable and immovable property in most cantons are charged for the ownership of property rather than use of property and would be classified under taxes on property rather than taxes on use of goods and on permission to use goods or perform activities, according to IMF (2014, p. 98). Still, we need to be careful as in all FBIH cantons, this type of property tax is area-based for immovable property and determined per $\mathrm{m}^{2}$, whereas movable propertymotor vehicles are determined per engine volume for motor vehicles and not by the value of assets or as percentage of the assessed property value which is defined under IMF (2014). Hence, there is a difference in definition and classification of taxes on movable property (here motor vehicles) in RS and FBIH since in RS motor vehicles are taxed based upon the use of motor vehicles and in FBIH based upon the ownership of motor vehicles. Obvious inter-entity differences in types of taxes on immovable property are already explained.

As shown in table 2, FBIH also applies real estate transfer tax which under OECD would be classified under Taxes on financial and capital transactions (4400). Difference between OECD and IMF classification under this category exists and is provided in table 1 . Some cantons in FBIH under real estate transfer tax also define the status of inheritance and gift taxes which under international practice should be classified separately. Overview of cantonal real estate transfer taxes is provided in table 2. Prior to 2009, real estate transfer tax rates differed from 5 per cent up to $8^{4}$ per cent but since then they were mostly harmonised at the level of up to 5 per cent. Hence, most cantons set the tax rate at exactly 5 per cent, but some set the tax rate of up to 5 per cent (for example Herzegovina-Neretva Canton) giving LGUs and local assemblies an option to determine their own tax rates. Cantonal laws also define the revenue sharing mechanism. Both types of property taxes are mostly shared between cantons and LGUs. Current situation regarding characteristics of both types of taxes and revenue sharing mechanism for each canton is summarised in table 2. Results in table 2 might indicate unequal treatment between LGUs in terms of revenue sharing between cantons in FBIH. This affects local revenues on one side and on the other, the provision of local public goods, for example communal services, which are traditionally provided at the local level. FBIH or RS do not apply any additional types of user charges related to ownership of the real estate.

Based upon our prior analysis, we can determine that there are significant inter-entity differences in the classification of taxes on property in BIH and little comparability with international practice. The provided examples of taxation

4 Zenica-Doboj Canton applied a rate of 8 per cent until 2009. 


\section{Lejla Lazović-Pita, Amina Močević}

of types of movable property (i.e. motor vehicles) is different in two entities and not in accordance with the classification under taxes on property.

Table 2: Property taxes in FBIH, 2018

\begin{tabular}{|c|c|c|c|c|c|c|c|}
\hline \multirow[t]{2}{*}{ Canton } & \multirow{2}{*}{ 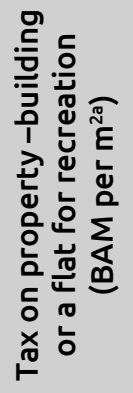 } & \multirow{2}{*}{ 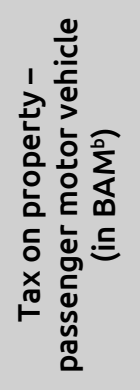 } & \multicolumn{2}{|c|}{  } & \multirow{2}{*}{  } & \multicolumn{2}{|c|}{ 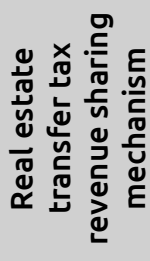 } \\
\hline & & & C & L & & C & L \\
\hline Una-Sana Canton & 2 & $10-70$ & 0 & 100 & up to $5 \%$ & 0 & 100 \\
\hline Posavina Canton & 1 & $25-100$ & 50 & 50 & $5 \%$ & 50 & 50 \\
\hline Tuzla Canton & 1 & $20-300$ & 0 & 100 & $5 \%$ & 0 & 100 \\
\hline $\begin{array}{l}\text { Zenica-Doboj } \\
\text { Canton }\end{array}$ & 1 & $10-100$ & 0 & 100 & $5 \%$ & 0 & 100 \\
\hline $\begin{array}{l}\text { Bosnian-Podrinje } \\
\text { Canton Goražde }\end{array}$ & 2 & $100-200$ & 50 & 50 & $5 \%$ & 50 & 50 \\
\hline $\begin{array}{l}\text { Central Bosnia } \\
\text { Canton }\end{array}$ & 1 & $30-300$ & 20 & 80 & $5 \%$ & 5 & 95 \\
\hline $\begin{array}{l}\text { Hercegovina- } \\
\text { Neretva Canton }\end{array}$ & 1,5 & $10-250$ & 50 & 50 & up to $5 \%$ & 0 & 100 \\
\hline $\begin{array}{l}\text { West-Hercegovina } \\
\text { Canton }\end{array}$ & 2 & $20-100$ & 0 & 100 & $5 \%$ & 50 & 50 \\
\hline Sarajevo Canton & 3 & $50-250$ & 60 & 40 & $5 \%$ & 0 & 100 \\
\hline Canton 10 & 2 & $10-250$ & 75 & 25 & $5 \%$ & 30 & 70 \\
\hline
\end{tabular}

a an example of immovable property.

b an example of movable property. Limits within each canton are different and they depend on the engine volume $\left(\mathrm{m}^{3}\right)$ and the age of motor vehicle.

${ }^{\mathrm{C}} \mathrm{C}$ - canton, and L-municipality or city (local community).

Source: own interpretation based upon Todorović, 2017.

\section{Comparative Analysis of Taxation of Property in BIH}

Regarding taxation of property in $\mathrm{BIH}$, we also wish to determine the size and significance of taxes on property in both entities and to evaluate whether there is a possibility of taking advantage of greater fiscal space in property taxation. Hence, we firstly evaluate the size and share of property tax rev- 
enues to total revenues and to total local revenues in RS. Bearing in mind aforementioned legal changes, table 3 shows the share of the property tax revenues to total and local revenues in RS for 2005-2017. We use standard OECD/EC measure of the share of property tax revenues to total revenues and total local revenues over 2005-2017 period.

Table 3: The share of property tax revenues to total and local revenues in RS, $2005^{5}-2017$, in per cent

\begin{tabular}{|c|c|c|c|c|c|c|c|c|c|c|c|c|c|}
\hline & 옹 & ○̊ & 응 & 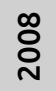 & 용 & 응 & $\underset{\sim}{\circ}$ & $\underset{N}{N}$ & $\stackrel{m}{\text { D }}$ & $\stackrel{\Xi}{\stackrel{N}{N}}$ & $\stackrel{\text { ㅁ }}{\stackrel{N}{N}}$ & $\stackrel{0}{\circ}$ & 훙 \\
\hline $\begin{array}{l}\text { Share of property } \\
\text { tax revenues to } \\
\text { total revenues } \\
\text { in RS }\end{array}$ & 1.6 & 0.8 & 0.8 & 1.0 & 0.7 & 0.6 & 0.5 & 0.4 & 0.7 & 0.6 & 0.6 & 0.6 & 0.6 \\
\hline $\begin{array}{l}\text { Share of property } \\
\text { tax revenues to } \\
\text { total local reve- } \\
\text { nues in RS }\end{array}$ & 8.3 & 4.1 & 4.0 & 5.0 & 3.6 & 3.8 & 3.4 & 2.8 & 4.6 & 4.3 & 4.0 & 3.9 & 4.1 \\
\hline
\end{tabular}

Source: Central bank of BIH, 2018, own calculation.

For the overall period 2005-2017, we can generally determine a downward trend in revenues from property taxes in RS. However, if the intention of legislator was to conduct a revenue-neutral reform with the implementation of taxes on immovable property as of 2012, then this trend (after 2012) could be assessed as positive. This could also be confirmed in the share of property tax revenues to total local revenues since 2012. Furthermore, it is reasonable to assume that now revenues from property taxes are more easily predictable and stable which are two (out of three) major advantages of property taxes (McCluskey and Plimmer, 2011). Third possible advantage related to increased simplicity in RS was not fully met by now and is explained in Tadić (2016). However, with the introduction of taxes on immovable property in RS, RS broadened the tax base and on several occasions since 2012 lowered the tax rates which could bring multiple positive effects to property markets in RS and hence creation of greater fiscal space. McCluskey and Plimmer (2011) also argue that this could lead to a possible increase in market value of property in RS and expansion of property market in RS. Until today, publicly available data for a more comprehensive empirical research of such effects is scarce but is expected in the future research.

From table 3 we can also determine that revenues from property taxes to total revenues in RS in the pre-crisis period of 2005-2008 were unstable. However, they can be explained by prior legal changes that occurred in RS until 2008. Since 2009 until 2016, revenues from property taxes have been increasing except 2012 when recurrent tax on immovable property became opera-

5 Official data is not available for years 2003-2004 and 2016 is the latest available data. 
tional and when real estate transfer tax was abolished. Overall, the share of revenues from property taxes to total revenues is very low and amounts to on average (2005-2017) to $0.7^{6}$ per cent. In the total local revenues, the share is somewhat different. The volatile trend in the share of property tax revenues to total local revenues in RS could be explained by other tax revenues taking predominance in the revenue structure. This relates to the introduction of VAT in 2006 in BIH which increased overall tax revenues, hence the share of property tax revenues was lower in comparison to 2005. Again, the abolishment of real estate transfer tax in 2012 caused a significant fall in the share of revenues from property taxes to total local revenues.

During this period, the position of LGUs in RS in terms of revenues from property taxes differed. With the application of new recurrent tax on immovable property, LGUs were given greater responsibilities and autonomy as they could set the tax rates on their own not exceeding the upper legal limit. With the increase in local autonomy, aspects of fiscal decentralisation in RS increased and might be considered as positive. However, relatively inexperienced LGUs which did not perform any in-depth analysis of possible effects of newly gained responsibilities have, in turn, created a property tax jungle with a spectrum of tax rates brought and adopted by local assemblies. Tadić (2016, p. 145-146) argues that local tax collectors entered the process "unprepared and understaffed" especially since there was a lack of coordination from RS level to the local level. Additionally, the estimated value of immovable property differed substantially between LGUs and citizens filed many complaints which postponed the tax collection process and caused a fall in tax revenues. Tadić (2016) further argues that LGUs had set the tax rates inadequately as some developed LGUs and undeveloped LGUs had the same tax rates. So, even though fiscal decentralisation improved with the transfer of authority to LGUs, fiscal equalisation between developed and undeveloped LGUs was considered as unsuccessful in practice.

Since FBIH still applies two types of property taxes, we would expect revenues from property taxes to have a higher share in total revenues. This can be confirmed from data given in table 4 for the entire observed period 20032017. In the pre-crisis period there is an instability in the share of property tax revenues to total revenues. Similar can be determined after 2008 . However, if we look at the revenues from property taxes in both FBIH and RS in absolute terms they have been mostly increasing in the pre-crisis period, were volatile in the 2008-2012 period and more or less stable after 2013. The share of property tax revenues to total revenues in FBIH (2003-2017) is somewhat higher than in RS and on average amounts to 1.2 per cent. The share of property tax revenues to total local revenues in FBIH is higher than in RS. The reason for high share in the pre-2006 period in FBIH is the same as in RS case - with the introduction of VAT in 2006, indirect tax revenues took predominance

6 This percentage is even lower in comparison to GDP which undermines the creation of greater fiscal space under property taxes in RS even in comparison to CEE countries. 
in the revenue structure at local level. However, the share of property tax revenues to total local revenues in $\mathrm{FBIH}$ amounts to 9.7 per cent on average (2008-2017) which is more than two times higher than the same ratio in RS (average is 4 per cent, 2008-2017). Hence, we can confirm that property tax revenues to total or local revenues are higher in FBIH than in RS and are the result of more types of property tax applied in FBIH. However, unlike FBIH which has done very little in the property tax reforms unlike RS, it is reasonable to expect that property tax revenues should increase in future in RS especially since they now they are more predictable and stable. In that sense, property tax reforms in cantons in FBIH should be set as a priority tax policy.

Table 4: The share of property tax revenues to total and local revenues in FBIH, 2003-2017, in per cent

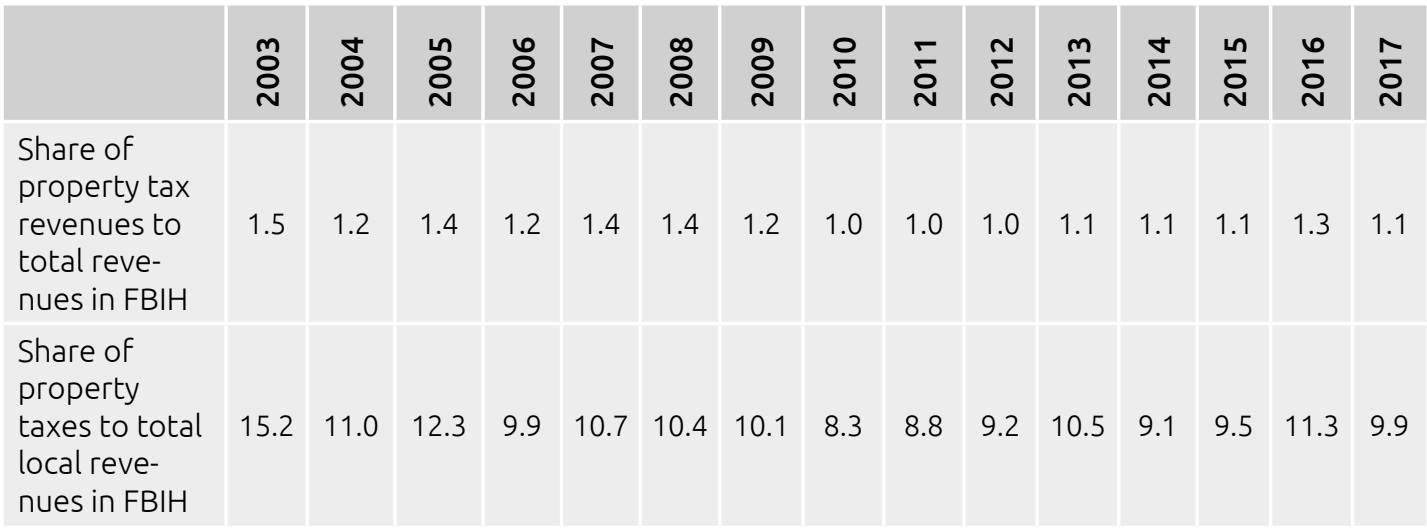

Source: Central bank of BIH, 2018, own calculation.

\subsection{Taxation of property in FBIH with a special focus of Sarajevo Canton}

The relatively high share of property tax revenues to total or local revenues in FBIH needs to be further analysed. Hence, this section provides answers to two questions: what is the most significant type of property tax that ensures high property tax revenues in FBIH and where is that type of property tax mostly collected? Evidence in figure 1 indicates that in whole of $\mathrm{FBIH}$, the highest revenue collection from property taxes - both property and real estate transfer tax is collected in Sarajevo Canton. Over the past six years in absolute and in relative terms, Sarajevo Canton has collected the highest revenues from property taxes compared to all other cantons and it has recorded a growth in revenues from property taxes in each year in the observed period. Furthermore, it has collected twice as more revenues from property taxes (in absolute terms, 2012-2017) than all LGUs in RS. This is an expected result and was highlighted in the works of Zorn et al. (2000). 
Figure 1: Revenues from property taxes in ten cantons in the period 2012-2017

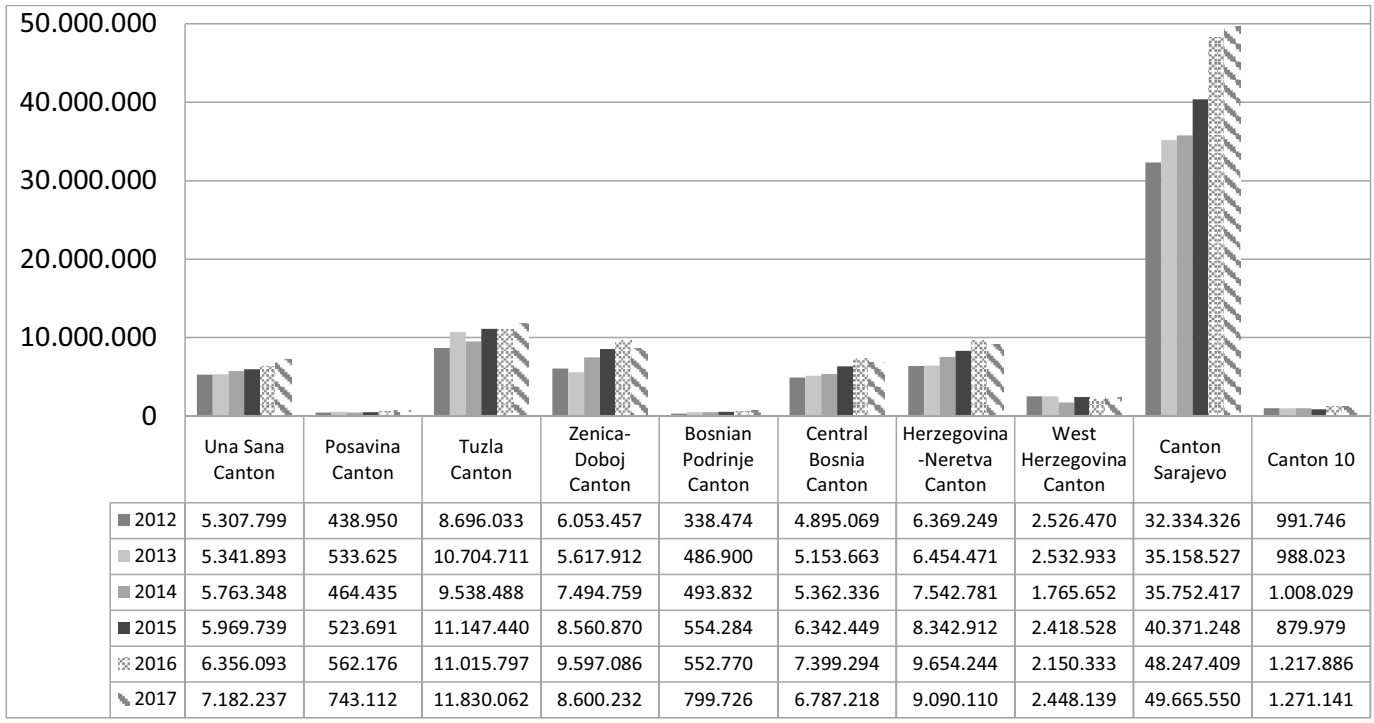

Source: Federal Ministry of Finance, 2017.

The share of revenues from property taxes to total revenues in ten FBIH cantons varied in the observed period. In fact, in nine cantons (excluding Sarajevo Canton) in 2017, the share of revenues from property taxes to total revenues was between 1.4 per cent in Canton 10 and Posavina Canton to 3 per cent in Herzegovina-Neretva Canton. Table 5 provides a summary of the share of revenues from property taxes to total revenues, 2012-2017. In most cantons, revenves were stable or had an increasing trend especially in the last three years.

Table 5: Share of revenues from property taxes to total revenues in ten cantons in FBIH, 2012-2017

\begin{tabular}{|l|c|c|c|c|c|c|}
\hline \multicolumn{1}{|c|}{ Canton/Year } & $\mathbf{2 0 1 2}$ & $\mathbf{2 0 1 3}$ & $\mathbf{2 0 1 4}$ & $\mathbf{2 0 1 5}$ & $\mathbf{2 0 1 6}$ & $\mathbf{2 0 1 7}$ \\
\hline Una Sana Canton & 2.3 & 2.4 & 2.4 & 2.4 & 2.4 & 2.7 \\
\hline Posavina Canton & 1.1 & 1.6 & 1.0 & 1.1 & 1.0 & 1.4 \\
\hline Tuzla Canton & 2.0 & 2.7 & 2.2 & 2.4 & 2.4 & 2.4 \\
\hline Zenica-Doboj Canton & 1.8 & 1.7 & 2.1 & 2.2 & 2.5 & 2.1 \\
\hline Bosnian Podrinje Canton & 0.8 & 1.3 & 1.0 & 1.2 & 1.3 & 1.9 \\
\hline Central Bosnia Canton & 2.4 & 2.5 & 2.5 & 2.8 & 3.0 & 2.6 \\
\hline Herzegovina-Neretva & 2.6 & 2.6 & 2.8 & 2.8 & 3.3 & 3.0 \\
\hline Canton & 2.9 & 2.9 & 1.9 & 2.5 & 2.0 & 2.1 \\
\hline West Herzegovina Canton & 4.4 & 4.9 & 4.7 & 4.9 & 5.7 & 5.3 \\
\hline Canton Sarajevo & 1.3 & 1.3 & 1.2 & 1.0 & 1.3 & 1.4 \\
\hline Canton 10 & & & & &
\end{tabular}

Source: Federal Ministry of Finance, 2017, own calculation. 
In comparison to other cantons in FBIH which mostly include several smaller cities, Sarajevo Canton has a special position of a canton-city. In comparison to pre-war territory and number of municipalities forming a City of Sarajevo, both have decreased under new BIH constitution. Currently, Sarajevo Canton includes nine municipalities. Four inner city municipalities form a City of Sarajevo ${ }^{7}$. Most population in Sarajevo Canton live in City of Sarajevo which, in comparison to pre-war expenditure assignments has now transferred its responsibilities to cantonal level. This causes several issues especially in the provision of communal services due to the fact that most of pre-war communal infrastructure changed very little. In addition, Sarajevo Canton unlike most other cantons in FBIH has not yet adopted Law on Local Self-Government which further complicates the expenditure assignment as well as revenve allocation and hence the sharing mechanism between Sarajevo canton and LGUs (table 2).

In terms of revenue sharing mechanism, Sarajevo Canton is in a unique position as a city-canton since most revenues belong to Sarajevo Canton. This is not only the case with property tax revenues (table 2), but also with other revenues (for example, personal income tax revenues). As an answer to the question - what is the most significant type of property tax that ensures high property tax revenues in $\mathrm{FBIH}$, the answer is that most revenues from property taxes come from real estate transfer tax which, on average (2014-2016) amounted to over 72 per cent of all revenues from property taxes (Sarajevo Canton Ministry of Finance, 2017, own calculation). Due to lack of officially available data, it is reasonable to assume that the highest share of property tax revenues in all ten cantons in FBIH also comes from real estate transfer tax revenues. The allocation of revenues from real estate transfer tax is different in inner and outer city LGUs in Sarajevo Canton. Inner city LGUs share revenues with City of Sarajevo so that 30 per cent of revenues from real estate transfer tax belongs to City of Sarajevo and the remaining 70 per cent to inner city LGU. All revenues from real estate transfer tax in the outer-city municipalities fully belong to local communities in which they were collected (table 2). Di Bella et al. (2017, p.15) argue that „the large cross-regional dispersion of per capita own revenues may have contributed to economic and population concentration, which creates negative spillovers for regions with population outflows". However, Sarajevo Canton through the allocation of real estate transfer tax attempts to support the development of outer-city municipalities and the share of property taxes to total revenues of these municipalities is higher than in inner-city municipalities.

7 Four inner city municipalities are: Centar, Stari Grad, Novi Grad and Novo Sarajevo. Five outer-city municipalities are: Vogošća, Ilijaš, llidža, Trnovo and Hadžići. 


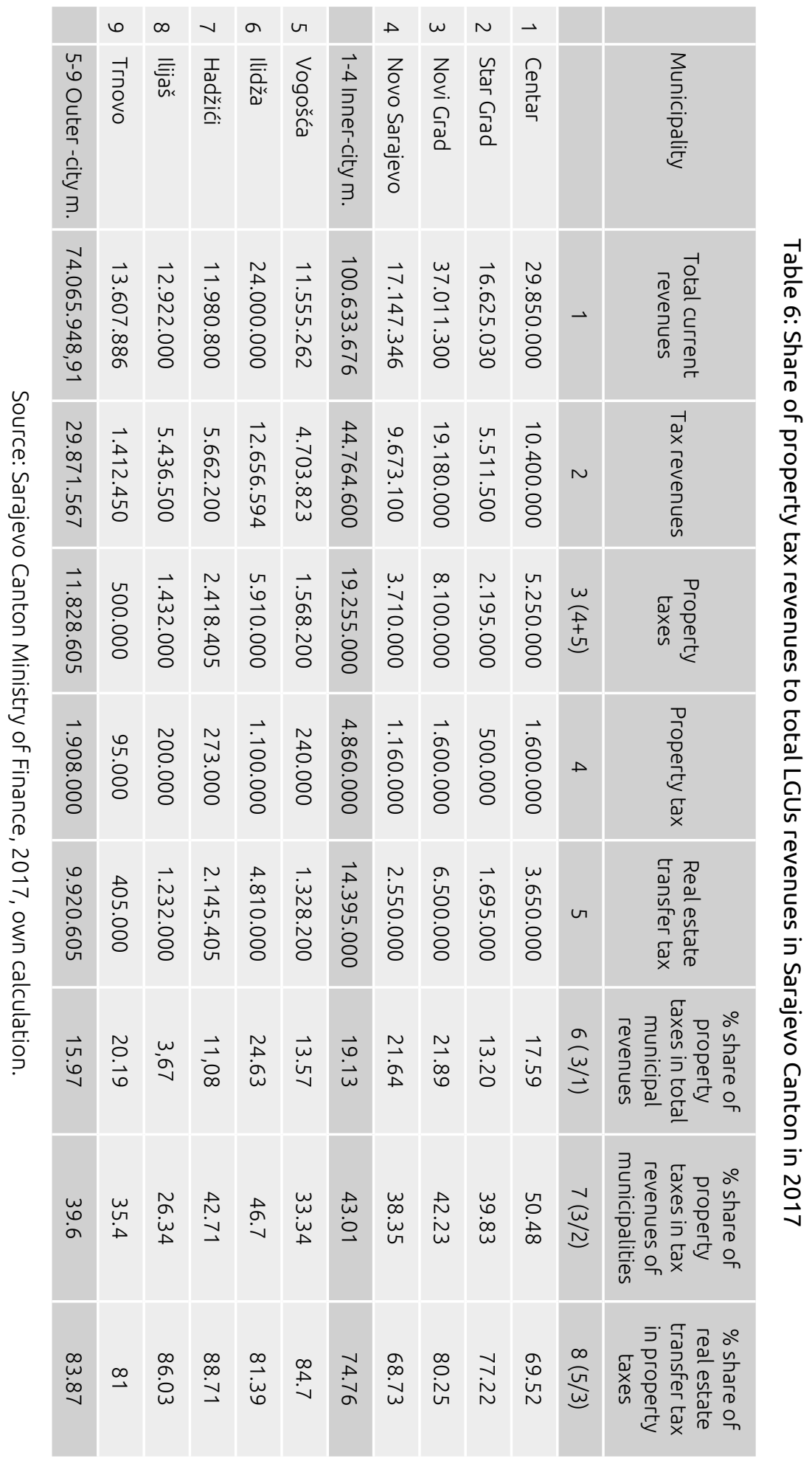


The higher share of revenues from real estate transfer tax to total local revenues confirms that property tax revenues should be allocated at local level since they are more easily predictable and stable source of revenues (McCluskey and Plimmer, 2011). Furthermore, this corresponds to ideas presented in the first and second theory of fiscal federalism (Oates, 1999; Weingast, 2005). Although inner-city municipalities have been collecting more revenues from real estate transfer taxes than outer-city municipalities in absolute terms, in relative terms, the percentage share of the real estate transfer tax in total local revenues from property taxes is higher in outer-city municipalities.

There are a few reasons that might explain this issue. The first one relates to revenue sharing mechanism from real estate transfer tax so that outer-city municipalities collect all revenues whereas inner-city municipalities are entitled to 70 per cent of collected revenues. Secondly, Sarajevo Canton does not tax land through tax on property which causes lower revenues from property taxes in outer-city municipalities in comparison to inner-city municipalities. Total area of Sarajevo Canton is $1.276 .9 \mathrm{~km}^{2}$. The share of territory of four inner city municipalities amounts to only 11.1 per cent and the rest (88.9 per cent) belongs to five outer-city municipalities. Hence, five-outer city municipalities have a significant potential in terms of creation of greater fiscal space for property taxation in the future. Finally, our results show that in 20142016 period there have been significant land-related real estate transfers and therefore paid taxes in outer-city municipalities. In fact, two year (20142016) average of all real-estate transfers in outer-city municipalities related to land transfers amounted to 62.5 per cent in comparison to 37.5 per cent in inner-city municipalities (Sarajevo Canton Tax Administration, 2016, own calculation). However, due to lack of official data on ownership, market value or the size of traded property (in $\mathrm{m}^{2}$ ) further empirical analysis is limited. It is reasonable to assume that the value of taxed land in inner-city municipalities in comparison to outer-city municipalities is much higher which again is shown through the size of collected revenues (table 6).

\section{Recommendations and Conclusion}

Due to a complex constitutional organisation of BIH of a two entity state, the taxation of property in two BIH entities is organised differently. Additional reasons for inter-entity disparities also exist such as different constitutional organisation of entities itself and more importantly, different approaches to taxing property. We have determined that BIH currently applies three types of property taxes and that BIH classification of types of property differs to international classifications of IMF or OECD. In entity RS, property is taxed through recurrent tax on immovable property whereas in $\mathrm{FBIH}$, property taxes are under cantonal jurisdiction and include taxes on property and real estate transfer taxes which in some cantons also include inheritance and gift taxes. Legal differences in two entities show their effects on the size of collected revenues from property taxes whereas in $\mathrm{FBIH}$ the share of revenues 
from property taxes to total revenues is higher than in RS. More importantly, the revenues from property taxes to total local revenues are higher in $\mathrm{FBIH}$ than in RS even though they are not the main source of local revenues in either entity (indirect tax revenues take the highest share). The analysis showed that the highest share of revenues from property taxes in $\mathrm{FBIH}$ is collected in Sarajevo Canton. Hence, we have analysed the position of Sarajevo Canton in more detail. More than seventy percent of property tax revenues are generated from real estate transfer tax revenues in both inner and outer-city municipalities. Due to lack of official data, similar situation could be assumed in other nine cantons in terms of the share of real estate transfer tax revenues to total property tax revenues. In addition, the importance of revenues from property taxes in inner and outer-city municipalities in Sarajevo Canton are different. Revenues from property taxes to total local revenues are more significant in the outer-city municipalities.

Due to its significance to local revenues, in terms of set of recommendations and suggestions, any future property related tax reforms should be carefully tailored in $\mathrm{BIH}$ and especially in $\mathrm{FBIH}$.

In $\mathrm{BIH}$, types of taxes on property should firstly be classified in accordance with international classifications. This especially relates to classification of taxation of movable property in both BIH entities. Our analysis showed that property tax reforms in RS are more advanced than in FBIH which faces several problems. Even though most property tax revenues are collected in $\mathrm{FBIH}$, with an adequate property tax reform in $\mathrm{FBIH}$, all advantages of property taxes related to simplicity, predictability and stability of revenues could be fulfilled. Similar is expected in RS in the coming years. Additionally, adequate property tax reform is very important to economic growth. Most recent research from Grdinić et al. (2017) proved that property taxes out of all direct taxes have the least detrimental impact to economic growth in CEE countries. Secondly, all ten FBIH cantons need legislative changes and abolishment of current 'taxes on property' and real estate transfer taxes in the future. FBIH property tax reforms should focus on introducing recurrent taxes on immovable property similar to RS case. However, this reform needs to be carefully planned bearing in mind lessons learned from CEE practice (Grover et al, 2017; Puleri \&Kripa, 2017). Thirdly, some activities as a precondition to property tax reforms have already begun in late 2016. Similar to Slovenian case in the late 1990s, the World Bank has initiated an international project for modernizing the records of real estate transactions as of fiscal year 2017. All current transactions from real estate transfer tax in FBIH are being recorded with all necessary data (ownership, market value, contract value, the size of traded property) which could in turn speed up the process of the development of a model for mass valuation of property. Additionally, the World Bank also initiated a project of harmonisation of Land registries in FBIH which could in turn result in a reliable land register and can lead to the establishment of fiscal cadastre. Hence, Grover et al. (2017) have already provided the results of a similar World Bank 
activities conducted in eight ECA countries which face similar property related issues (in comparison to Dutch case). Thirdly, long-term property tax reform in FBIH should include property-tax base broadening for categories that are currently left untaxed such as land. This way, LGUs could take advantage of greater fiscal space created under property taxes. Fourthly, in terms of lessons learned from RS experience, in order to successfully implement property tax reform in FBIH, FBIH should improve institutional cooperation and communication (for example, improved cooperation between Cantonal Ministries of Finance and Cantonal Tax administrations or Cantonal Ministries of Finance with Federal Ministry of Finance/Federal Administration for Geodetic and Real Property Affairs). Better coordination should also be expanded to cooperation between cantonal ministries of finance and cantonal tax administration on one side and Land Registries and Municipal Cadastres on the other. Finally, during this process, a set of other legal changes should follow property tax reform in FBIH giving more fiscal autonomy to LGUs which is in line with first and second generation of fiscal federalism. We have determined that revenues from property taxes are becoming more predictable, stable and important source of revenues for LGUs in RS and in FBIH, so the possible switch from current two types of property taxes in FBIH to one more comprehensive recurrent tax on immovable property could be more easily achieved bringing aspects of tax simplification into FBIH property tax system.

Bearing in mind the limitations of this paper primarily related to lack of official long term data, once the official data from current property-related activities in both RS and FBIH becomes publicly available, we expect to expand our analysis to more quantitative and empirical measures of the impact that property taxes and property tax reforms have had on economic growth, evaluation of implementation of property tax reforms in $\mathrm{FBIH}$ and the impact of property tax reforms on LGUs and the level of fiscal decentralisation in $\mathrm{BIH}$. 


\section{References}

Almy, R. (2001). A survey of property tax systems in Europe. A report prepared for Slovenian Ministry of Finance. At: <agjd.com/EuropeanPropertyTaxSystems.pdf>, accessed 12 June 2018.

Almy, R. (2014), „Valuation and Assessment of Immovable Property«, OECD Working Papers on Fiscal Federalism, No. 19, OECD Publishing, Paris, <https://doi.org/10.1787/5jz5pzvr28hk-en>.

Antić, D. (2013). Multi-level fiscal system in Bosnia and Herzegovina: evolution and coping with economic crisis. Financial Theory and Practice, 37 (3), pp. 279-310.

Arnold, J. (2008). Do Tax Structures Affect Aggregate Economic Growth?: Empirical Evidence from a Panel of OECD Countries", OECD Economics Department Working Papers, No. 643, OECD Publishing, Paris.

Arnold, J.M., Brys, B., Heady, C., Johansson, A., Schwellnus, C., and Vartia, L. (2011). Tax Policy for Economic Recovery and Growth. The Economic Journal, 121 (550), pp. 59-80.

Bahl, R. (2009). Property Tax Reform in Developing and Transition Countries. A report prepared for the United States Agency for International Development under a contract with Development Alternatives, Inc. under the Fiscal Reform and Economic Governance Task Order, GEG-I-00-04-00001-00 Task Order No. 07.

Blažić, H. and Grdinić, M. (2012). Porez na imovinu u EU. In Z. Prohaska, M. Dimitrić and H. Blažić, eds., Financijska tržišta i institucije R Hrvatske u procesu uključivanja u Evropsku uniju. Rijeka: Ekonomski fakulet, Sveučilište u Rijeci, pp. 71-91.

Blažić, H. (2006). Usporedni porezni sustavi - oporezivanje dohotka i dobiti. At: <https://www.efri.uniri.hr/sites/efri.hr/files/cr-collections/2/h.blazic_usp_ por_sustavi-knjiga-1363785054.pdf>, accessed 21 June 2018.

Blažić, H., Šimović, H. and Štambuk, A. (2016). Area Based versus Value Based Recurrent Taxation of Immovable Property. In M. Benazić, M. Božina Beros, G. Gimigliano, A. Novak, D. Učkar, eds., The EU Economic Environment Postcrisis: Policies, Institutions and Mechanisms. Pula: Juraj Dobrila University of Pula, pp. 35-46.

Blöchliger, H. (2015). Reforming the Tax on Immovable Property: Taking Care of the Unloved, OECD Economics Department Working Papers, No. 1205. Paris: OECD Publishing.

Brandt, N. (2014). Greening the Property Tax, OECD Working Papers on Fiscal Federalism, No. 17. Paris: OECD Publishing.

Central bank of BIH. (2018). Statistički web portal CBBIH. At: <https://www.cbbh. ba/content/read/915>, accessed 12 July 2018.

Davey, K. (ed.) (2011). Local Government in Critical Times: Policies for Crisis, Recovery and a Sustainable Future. Strasbourg: Council of Europe. At: <https:// rm.coe.int/16807472af>, accessed 5 June 2018.

Di Bella, G., Dynnikova, O. and Grigoli, F. (2017). Fiscal Federalism and Regional Performance. IMF Working paper 17/265.

European System of Accounts (ESA). (2010). About ESA 2010. At: <http:// ec.europa.eu/eurostat/web/esa-2010>, accessed, 12 June 2018.

Federal Ministry of Finance. (2017). Overview of allocated public revenues between the budget of the canton and the budgets of municipalities (different years). At: <www.fmf.gov.ba>, accessed 5 July 2018. 
Fox, W. and Wallich, Ch. (1997). Fiscal federalism in Bosnia-Herzegovina: The Dayton challenge (English). Policy, Research working paper; no. WPS 1714. Washington, DC: World Bank. At: <http://documents.worldbank.org/curated/ en/251741468767989572/Fiscal-federalism-in-Bosnia-Herzegovina-The-Dayton-challenge>, accessed 5 September 2018.

Garnier, G.,György, E., Heineken, K., Mathé, M., Puglisi, L., Ruà, S., Skonieczna, A. and Van Mierlo, A. (2014). A wind of change? Reforms of Tax Systems since the launch of Europe 2020. EC Taxation paper, No 49. At: <https://ec.europa. eu/taxation_customs/sites/taxation/files/resources/documents/taxation/ gen_info/economic_analysis/tax_papers/taxation_paper_49.pdf>, accessed 10 September 2018.

Gayer, C. and Mourre, G. (eds.) (2012). Property taxation and enhanced tax administration in challenging times. Proceedings of the workshop organised by the Directorate General for Economic and Financial Affairs held in Brussels on 24 November 2011. European Commission, Economic Papers 463. At: <http:// ec.europa.eu/economy_finance/publications/economic_paper/2012/pdf/ ecp_463_en.pdf>, accessed 10 September 2018.

Grdinić, M., Drezgić, S. and Blažić, H. (2017). An Empirical Analysis of the Relationship between Tax Structures and Economic Growth in CEE Countries. Ekonomicky Casopis, 65 (5), pp. 426-447.

Grover, R., Torhonen, MP, Munro-Faure, P., and Anand, A. (2017). Achieving successful implementation of value-based property tax reforms in emerging European economies. Journal of European Real Estate Research, 10 (1), pp. 91-106.

IMF. (2014). Government finance statistics manual. At: <https://www.imf.org/external/Pubs/FT/GFS/Manual/2014/gfsfinal.pdf>, accessed 10 June 2018.

Jelčić, B. and Jelčić, B. (1998). Porezni sustav i porezna politika. Zagreb: Informator.

Johansson, A.., et al. (2008), »Taxation and Economic Growth«, OECD Economics Department Working Papers, No. 620. Paris: OECD Publishing.

Jokay, C. (2001). Local Government in Bosnia and Herzegovina. In. E. Kandeva, ed., Stabilization of Local Governments. Budapest: Open society institute. At: <http://pdc.ceu.hu/archive/00006992/01/LGl_Stabilization-of-Local-Governments_2001.pdf>, accessed 15 June 2018.

Kukić, N. and Švaljek, S. (2012). Porez na nekretnine: osnovne značajke i rasprava o uvođenju u Hrvatskoj. Privredna kretanja i ekonomska politika, 22 (32), pp. 41-92.

Malme, J., and Youngman, J. (eds). (2001). The Development of Property Taxation in Economies in Transition: Case Studies from Central and Eastern Europe. WBI Learning Resources Series. Washington: The World Bank.

McCluskey, W. J. Plimmer, F., and Connellan, O.P. (2002). Property Tax Banding: A Solution for Developing Countries. Assessment Journal, 9(2), pp. 37-47.

McCluskey, W.J. and Plimmer, F. (2011). The Creation of Fiscal Space for the Property Tax: The Case of Central and Eastern Europe. International Journal of Strategic Property Management, 15 (2), pp. 123-138.

Norregaard, M. J. (2013). Taxing Immovable Property Revenue Potential and Implementation Challenges IMF Working paper 13-129. IMF. At: <https://www. imf.org/external/pubs/ft/wp/2013/wp13129.pdf>, accessed 10 September 2018. 
Oates, W. E. (1999). An Essay on Fiscal Federalism. Journal of Economic Literature, 37 (3), pp. 1120-1149.

OECD (2006). Fundamental Reform of Personal Income Tax, OECD Tax Policy Studies, no. 13, Paris: Éditions OECD.

OECD (2017). The OECD classification of taxes and interpretative guide, dans Revenue Statistics: 1965-2016. Paris: Éditions OECD.

Puleri, T. and Kripa, D. (2016). Real Estate Taxation System in Albania and Challenges for a European Fiscal System. Basiq International Conference - New Trends in Sustainable Business and Consumption. Konstanz (2-3 June 2016.), pp. 242-250.

Raičević, B. (2008). Javne finansije. Beograd: Centar za izdavačku delatnost.

Rašić Bakarić, I. (2014). Osnovne značajke poreza na nekretnine: njegova primjena u Hrvatskoj i ostalim zemljama članicama Europske unije, Ekonomski pregled, 65(5), pp. 385-415.

Sarajevo Canton Ministry of Finance. (2017). Consolidated revenues of Sarajevo Canton 2012-2017. Unpublished.

Sarajevo Canton Tax Administration. (2016). Real estate transfer tax register 2014-2016. Unpublished.

Slack, E. and R. Bird (2014), "The Political Economy of Property Tax Reform", OECD Working Papers on Fiscal Federalism, No. 18, OECD Publishing, Paris. http://dx.doi.org/10.1787/5jz5pzvzv6r7-en

Tadić, M. (2016). Ekonomski efekti poreza na nepokretnost. Economics, 4(1), pp. 137-150. At: <http://oikosinstitut.org/wp-content/uploads/2016/11/casopis6.pdf\#page=143>, accessed 15 June 2018.

The European Commission (EC). (2015). Tax Reforms in EU Member States: 2015 Report. The European commission. 2015. Available at: <https://ec.europa. eu/taxation_customs/sites/taxation/files/resources/documents/taxation/ gen_info/economic_analysis/tax_papers/taxation_paper_58.pdf>, accessed 3 June 2018.

The European Commission (EC). (2017). Taxation trends in the EU -2017 edition. At: <https://ec.europa.eu/taxation_customs/node/968_en>, accessed 10 June 2018.

The World Bank (1999). Ad valorem property taxation and transition economies (English). ECSIN working paper ; no. 9. Washington, DC: World Bank. At: <http://documents.worldbank.org/curated/en/164781468779695399/Ad-valorem-property-taxation-and-transition-economies>, accessed 15 July 2018.

Todorović, Lj. (2017). Priručnik o porezima i doprinosima. Sarajevo: Fineks.

Weingast, B.R. (2005). Second generation fiscal federalism: The implications of fiscal incentives. Journal of Urban Economics, 65 (3), pp. 279-29.

Werner, J. Guihery, L., and Djukic, O. (2006). Fiscal Federalism in Bosnia and Herzegovina: Ten Years after the Dayton agreement and still not in a steady condition. Journal of Economic Asymmetries, 3, pp. 125-148.

Zorn, C.K., Tesche, J, and Cornia G. (2000). Diversifying Local Government Revenue in Bosnia-Herzegovina through an Area-Based Property Tax. Public Budgeting \& Finance, 20 (4), pp. 63-86. 